\title{
Peran Stratifikasi Sosial Masyarakat Pedesaan Terhadap Usaha Ternak Sapi Potong (Studi Kasus Di Desa Lompo Tengah Kec. Tanete Riaja Kab. Barru)
}

\author{
The Role of Social Stratification in Rural Community Againtst The Business \\ Cattle Farmers(Case Study: Lompo Tengah Village, \\ Tanete Riaja Sub-District, Barru District)
}

\author{
Mursidin*, Jumriah Syam \\ Jurusan Ilmu Peternakan, Fakultas Sains dan Teknologi \\ Universitas Islam Negeri Alauddin Makassar \\ *Korespondensi Email: mursidin.natsir@uin-alauddin.ac.id
}

\begin{abstract}
ABSTRAK
Penelitian ini bertujuan untuk mengetahui sejauhmana Peran Stratifikasi Sosial Masyarakat Perdesaan Terhadap Usaha Ternak Sapi Potong yang ada di Desa Lompo Tengah Kec. Tanete Riaja Kab. Barru. Metode yang digunakan dalam penelitian ini adalah FGD (Focus Group Discussion) dimana dalam FGD ini dilakukan proses wawancara secara langsung terhadap masyarakat sekitar serta instansi dan tokoh adat daerah penelitian dengan menggunakan alat interview guide (panduan wawancara). Hasil yang dicapai pada penelitian ini adalah stratifikasi sosial di Desa Lompo Tengah memiliki peranan yang berkaitan dengan harga diri yang merupakan hak yang dimiliki oleh setiap individu karena kedudukannya pada sebuah strata. Salah satu peternak berpendapat bahwa kondisi tentang peran stratifikasi sosial di Desa Lompo Tengah terbilang baik sebab hubungan antara pemimpin dan warga masyarakat khususnya peternak tetap dalam kondisi saling menghargai satu sama lain bahkan dari segi hak-hak yang telah dipenuhi terdistribusi secara merata tanpa melihat derajat dan statusnya. Sedangkan lain hal dengan pendapat pak Yendre, salah satu anggota kelompok tani/ternak di Desa Lompoh Tengah bahwa kelompoknnya kurang menjalin kerjasama, hanya di waktu tertentu saja seperti acara adat dsb. Namun dalam hal peternakan dan pertanian sangat kental bekerja secara induvidu meski mereka dalam sebuah kelompok seperti halnya dalam pemberian sapi potong betina produktif dan bantuan vaksin oleh pemerintah yang jarang didapatkan, hanya yang mendapatkan keluarga dari pemimpin adat atau yang sangat akrab dengan pemimpin adat.
\end{abstract}

Kata kunci : Stratifikasi Sosial, Pedesaan, Sapi Potong

\begin{abstract}
This study aims to understand the extent of the role of community social stratification rural on business the cattle producers and do beef cut into that existed in the village lompo tengah of sub-district. Tanete riaja district. Barru. The methodology that was used in this research was (fgd came up with a focus group discussions ) where is in discussions with these were done in the process of the objective of the interview directly against the people around the offices of
\end{abstract}


the local government as well as and leader village play the study areas by means of a utensil the interview. The results to research this is stratification social in the village lompo tengah having the role of pertaining to self-esteem that is the right of owned by every individuals because benefice upon a stratum. One farmers thought that the condition of the role of stratification social in the village lompo central quite good for the relationship between leader and residents especially farmers remain in the condition appreciate each other each other even in terms of rights that have been filled with distributed evenly without seeing degrees and status. While one thing with an opinion sir yendre, one member of the farmers to / livestock in the village lompoh tengah central that the group less cooperate, only in certain times as a customary ceremony etc. But in terms animal husbandry and agriculture are very resilient work in induvidu even though they in a group as is the case in the provision of beef cattle female productive and assistance vaccine by the government to which rarely obtained, only the get the family from the head of the customary or very familiar with leader customary.

Key words : Society Stratification, Village, Beef Catlle

\section{PENDAHULUAN}

Dalam rangka meningkatkan perekonomian masyarakat terutama pada sub sektor peternakan perlu adanya perhatian khusus, mengingat kondisi Indonesia cukup mendukung usaha budidaya dalam bidang peternakan. Peningkatan dan Pengembangan produk peternakan merupakan salah satu tujuan yang diharapkan untuk memajukan sub sektor peternakan khususnya ternak sapi potong. Kegiatan peternakan saat ini bukan hanya untuk memenuhi kebutuhan keluarga, tetapi sudah berkembang menjadi salah satu alternatif usaha yang menguntungkan. Selain itu ternak sapi dalam tatanan kehidupan rakyat Indonesia memiliki fungsi sosial dan ekonomi, oleh karena ternak dapat digunakan sebagai tenaga kerja pengolah lahan pertanian, sumber uang tunai, sumber pendapatan, upacara keagamaan, cendera mata, sumber pupuk organik, tenaga kerja dan dapat menaikkan status sosial pada komunitas tertentu

Pembangunan peternakan terutama pengembangan sapi potong perlu dilakukan melalui pendekatan usaha yang berkelanjutan, modern, dan profesional dengan memanfaatkan inovasi teknologi untuk meningkatkan efisiensi usaha. Selain itu, usaha sapi potong hendaknya didukung oleh industri pakan dengan mengoptimalkan pemanfaatan lokasi melalui pola yang terintegrasi. Untuk memenuhi kecukupan pangan, terutama protein hewani, pengembangan usaha peternakan yang terintegrasi merupakan salah satu pilar pembangunan sosial ekonomi. (Hamdi dkk, 2010).

Desa dimaknai sebagai suatu komunitas kecil yang menetap tetap di suatu tempat. Pemaknaan tentang desa menurut pandangan ini menekankan pada cakupan, ukuran atau luasan dari sebuah komunitas, yaitu cakupan dan ukuran atau luasan yang kecil, yang di dalamnya terdapat masyarakat yang hidup dengan keramahan dan keramahtamahan (Wahyuningsih, 2011). Ditambahkan lagi oleh Abu (2013) bahwa masyarakat terbentuk dari individu-individu. Individu yang terdiri dari berbagai latar belakang tentu akanmembentuk 
suatu masyarakat heterogen yang terdiri dari kelompok-kelompok sosial. Dengan adanya atau terjadinya kelompok sosial tersebut maka terbentuklah suatu pelapisan masyarakat atau terbentuklah masyarakat yang berstrata.

Menurut Munandar (2011) bahwa Stratifikasi sosial sebenarnya telah ada sejak zaman yunani kuno, hal tersebut dapat diketahui dengan adanya pendapat salah seorang filsuf yunani yaitu Aristoteles yang mengatakan bahwa di dalam negara terdapat tiga unsur, yaitu mereka yang tergolong kaya, menengah dan melarat, ditambahkan lagi oleh oleh Soerjono (2012) bahwa sistem lapisan sosial merupakan ciri yang tetap. Barangsiapa yang memiliki sesuatu yang berharga dalam jumlah yangsangat banyak dianggap berkedudukan dalam lapisanatas, sedangkan mereka yang hanya memiliki sedikit atau tidak memiliki sama sekali sesuatu yang berharga, maka dalam pandangan masyarakat mereka mempunyai kedudukan yang rendah.

Stratifikasi sosial adalah sebuah konsep yang menunjukkan adanya pembedaan dan/atau pengelompokan suatu kelompok sosial (komunitas) secara bertingkat. Misalnya: dalam komunitas tersebut ada strata tinggi, strata sedang dan strata rendah. Pembedaan dan/atau pengelompokan ini didasarkan pada adanya suatu simbol-simbol tertentu yang dianggap berharga atau bernilai baik berharga atau bernilai secara sosial , ekonomi, politik, hukum, budaya maupun dimensi lainnya dalam suatu kelompok sosial (komunitas). Pada waktu itu, istilah kelas sosial digunakan dalam konteks penggolongan masyarakat terhadap para pembayar pajak. Ketika itu ada dua masyarakat, yaitu masyarakat golongan kaya dan miskin (Ralf, 2013).

Kondisi di Desa Lompo Tengah dengan berbagai tingkatan serta kesetaraan masyarakat khususnya para peternak dalam mengembangkan usaha peternakan masih sangat kental, dengan mewariskan kepada generasi selanjutnya, konsep tersebut memberikan pemahaman kritis mengenai beragam fenomena sosial masyarakat dalam beternak. Dalam hirarki sosial masyarakat, orang yang memilki kekuasaan dapat dikatakan berada pada posisi yang lebih tinggi jika dibandingkan dengan mereka yang tidak memiliki kekuasaan, dengan kata lain kepemilikan ternak serta lahan di desa Lompo Tengah sangat berpengaruh untuk menunjang peningkatan usaha sapi potong, hal inilah yang dapat menjadi indikator pengukuran bahwa masyarakat yang memiliki lahan yang luas serta kepemilikan ternak merupakan masyarakat yang berada pada lapisan atas, namun dari lapisan masyarakat golongan atas hanya terbilang beberapa peternak. Maka dari fenomena inilah peneliti bermaksud melakukan penelitian mengenai peran staratifikasi sosial terhadap peternak sapi potong di Desa Tanete Riaja.Berdasarkan uraian di atas maka hal inilah yang melatarbelakangi dilakukannya penelitian mengenai "Peran Stratifikasi Sosial Masyarakat Perdesaan Terhadap Usaha Ternak Sapi Potong di Desa Lompo Tengah Kec. Tanete Riaja Kab. Barru.

Berdasarkan latar belakang yang telah diuraikan diatas, maka rumusan masalahnya adalah bagaimana peran stratifikasi sosial masyarakat pedesaan terhadap usaha ternak sapi potong. Tujuan dari penelitian ini yaitu untuk mengetahui peran stratifikasi sosial masyarakat pedesaan terhadap usaha ternak sapi potong. Hasil penelitian ini diharapkan 
dapat dijadikan sebagai sumber informasi kepada berbagai pihak terkait peran stratifikasi sosial masyarakat pedesaan terhadap usaha ternak sapi potong

\section{METODE PENELITIAN}

\section{Jenis dan Lokasi Penelitian}

Jenis Penelitian yang digunakan adalah penelitian kualitatif berupa fakta-fakta atau kejadian di lokasi penelitian yang berupa kalimat atau pernyataan yang sesuai dengan kebutuhan dalam penelitian ini.

Penelitian dilaksanakan pada bulan September sampai Oktober 2018 bertempat di Desa Lompo Tengah Kecamatan Tanete Riaja Kabupaten Barru, lokasi tersebut dipilih karena merupakan salah satu sentra peternakan sapi potong.

\section{Sumber dan Metode Pengumpulan Data}

Jenis dan sumber data yang digunakan dalam penelitian ini adalah:

1. Data primer merupakan data yang bersumber dari hasil wawancara secara langsung dan mendalam dari kelompok tani/ternak serta tokoh-tokoh adat di lokasi penelitian.

2. Data sekunder merupakan data yang bersumber dari instansi Pemerintah di Desa Lompo Tengah, Kecamatan Tanete Riaja Kabupaten Barru serta intansi pemerintah lainnya di Kabupaten Pinrang.

Metode pengumpulan data yang dilakukan pada penelitian di Desa Lompo Tengah, Kecamatan Tanete Riaja, Kabupaten Barru adalah FGD (Focus Group Discussion) dimana dalam FGD ini dilakukan proses wawancara secara langsung terhadap masyarakat sekitar serta instansi dan tokoh adat daerah penelitian. Yang dimaksud wawancara adalah proses memperoleh keterangan atau informasi untuk tujuan penelitian/pengamatan dengan cara tanya jawab kepada responden dengan menggunakan alat interview guide (panduan wawancara).

Kegiatan yang dilakukan pada penelitian mengenai Dampak Stratifikasi Sosial Dalam Masyarakat Perdesaan Terhadap Usaha Ternak Sapi Potong dengan menggunakan metode FGD (Focus Group Discussion). FGD merupakan suatu diskusi yang dilakukan secara sistematis dan terarah mengenai suatu masalah tertentu. FGD berfungsi sebagai satusatunya metode penelitian atau metode utama untuk pengumpulan data dalam penelitian. 


\section{HASIL DAN PEMBAHASAN}

\section{FGD (Focus Group Discussion) Desa Lompo Tengah Kec. Tanete Riaja Kab. Barru}

Berdasrkan FGD penyuluan peternakan yang dilakukan dibalai Desa Lompo Tengah diperoleh hasil wawancara, yaitu Kecamatan Tanete Riaja merupakan Kecamatan sentra populasi sapi potong yang unggul dalam hal produksi sapi potong. Sesuai catatan sejarah Kabupaten Barru pernah mengekspor sapi ke Inggris pada tahun 1970-an. Sentra pengembangan sapi bali murni di daerah Sulawesi Selatan terdapat di 3 kabupaten, yaitu Bone, Enrekang, dan Barru. Pada tahun 2014 Kecamatan tanete Riaja sudah mendapatkan SK dari Kementrian Pertanian sebagai pusat pembibitan sapi bali. Di Kecamatan tanete Riaja terdapat 24 kelompok tani/ternak, masing-masing kelompok tani/ternak diberikan fasilitas berupa timbangan, tongkat ukur, dan pita ukur. Sapi-sapi yang ada dikelompok tani/ternak Desa Lompo Tengah tidak boleh kawin saudara (inbreeding), hal ini dikarenakan akan mempengaruhi pertumbuhan dari sapi tersebut sehigga berdampak pada produktivitasnya. Maka dari itu kelompok tani ternak memiliki recording (pencatatan) terhadap sapi mereka.

Dalam hal pengendalian penyakit dan pemeriksaan kesehatan, dinas Petrnakan dan Kesehatan Hewan Kabupaten Barru bekerjasama dengan Balai Besar Veteriner (BBVET) Kabupaten Maros dalam hal pemeriksaan kesehatan terkhusus pada penyakit Brocelosis. Selain bekerjasama dengan BBVET Maros, Dinas Peternakan dan Keehatan Hewan Kabupaten Barru juga bekerjasama dengan Universitas Hasanuddin Fakultas Petenan dalam hal melaksanakan program pemerintahan, yaitu UPSUS SIWAB (Upaya Khusus Sapi Indukan wajib Bunting). Sebelumnya Universita Hasanuddin juga pernah bekerjasama dengan Balai Insiminsi Buatan yang ada di Kabupaten Barru.

Telah banyak pencapaian dalam hal produksi ternak di Kabupaten Barru, yaitu salah satunya pada tahun 2014-2015 telah menghasilkan pedet sapi bali dengan berat lahir $20 \mathrm{~kg}$ dan langsung terekspos di Kemntrian Pertanian yang merupakan hasil IB. Terkait pemasaran sapi potong pemerintah Kabupaten Barru telah melaksanakan program, yaitu Shorum Sapi. Shorum sapi merupakan program untuk memasarkan sapi potong yang didalamnya terdapat P3T Mandiri (Pos Pelayanan Peternakan Terpadu Mandiri) yang berfungsi untuk megetahui pelaporan hewan seperti program penanganan dan reaksi cepat. Dengan adanya P3T Mandiri, peternak bisa langsung melaporkan kondisi ternaknya ke Dinas Peternakan dan Kesehatan Hewan Kabupaten Barru. Sehingga dengan adanya semua 
sarana dan prasarana serta bentuk kerjasama dengan lembaga lain diharapkan mampu meningkatkan produksi ternak dan menjadikan Kabupaten Barru sebagai sentra sapi bali.

\section{Peran Stratifikasi Sosial Masyarakat Perdesaan Terhadap Peternak Sapi Potong}

Stratifikasi sosial di Desa Lompo Tengah memiliki peranan yang berkaitan dengan harga diri yang merupakan hak yang dimiliki oleh setiap individu karena kedudukannya pada sebuah strata. Dalam setiap strata ini ditandai dengan pangkat, simbul-simbul yang menonjol seperti peringkat atau peranan khusus dan juga tingkah laku dalam keseharian khususnya pada peternak sapi potong. Desa Lompo tengah terdapat orang-orang yang dihormati, berpendidikan memiliki kekuasaan dan wewenang serta memiliki kekayaan. Hal tersebut mengindikasikan adanya lapisan-lapisan yang disebut dengan stratifikasi sosial.

Dalam penelitian ini berbagai informasi terkait peran stratifikasi sosial terhadap peternak sapi potong di Desa Lompo Tengah telah didapatkan melalui hasil wawancara dengan metode FGD serta wawancara induvidu masing - masing pimpinan adat, penyuluh dan peternak. Berbagai pendapat telah didapatkan sesuai dengan kebutuhan dalam penelitian ini.

Pimpinan adat Desa Lompo Tengah berpendapat bahwa stratifikasi sosial yang terjadi di Desa Lompo Tengah memiliki peran yang cukup baik karena hubungan antara kepala desa dengan kelompok tani/ternak saling bekerja sama dalam mencpai tujuan kelompok tani/ternak yang disebabkan oleh tidak adanya keluhan dari peternak. Hal ini pun di kemukakan oleh salah satu peternak bahwa kondisi tentang peran stratifikasi sosial di Desa Lompo Tengah terbilang baik sebab hubungan antara pemimpin dan warga masyarakat khususnya peternak tetap dalam kondisi saling menghargai satu sama lain, bahkan dari segi hak-hak yang telah dipenuhi terdistribusi secara merata tanpa melihat derajat dan statusnya. Tanggapan ini diperkuat oleh Jimmy (2012), bahwa peran stratifikasi sosial yaitu untuk menyusun, mengatur, dan mengawasi hubungan manusia dalam suatu masyarakat.

Startifikasi social masyarakat di Desa Lompo Tengah berperan dengan baik karena hubungan antara kepala desa dengan kelompok tani yang memiliki pengelaman dalam beternak saling bekerjasama dan membantu dengan sesama kelompok tani/ternak dalam mencapai tujuan kelompok. Tanggapan ini diperkuat oleh Sastramiharja (2010), bahwa stratifikasi social dalam suatu masyarakat memiliki peran sebagai alat untuk 
mengkategorikan manusia ke dalam strata yang berbeda, maka dari situlah dapat menyederhanakan dunia manusia dalam konteks saling berhubungan.

Lain halnya yang dikatakan oleh salah satu peternak sapi potong di Desa Lompo Tengah tentang peran stratifikasi sosial masyarakat terhadap peternak dilihat dari distribusi hak-hak mereka masih kurang tepat sasaran sebagai contoh, pemberian pupuk bersubsidi untuk tanaman pakan hijauan pada kelompok tani dalam memelihara ternaknya yang berdampak negatif dalam segi pemberian pupuk tersebut, berdasarkan hasil wawancara secara induvidu dengan salah satu peternak, pembagian pupuk bersubsidi tidak merata disebabkan oleh beberapa hal tertentu misalnya hanya orang yang didalam keluarganya saja yang di proritaskan dan kurangnya informasi (tanpa di beritahukan) oleh pihak pendistribusi pupuk tersebut, hal inilah yang menandakan bahwa stratifikasi sosial di desa lompo tengah memiliki peranan yang berkaitan dengan harga diri/prestise atau privelese yang merupakan hak yang dimiliki oleh setiap individu karena kedudukannya pada sebuah strata. Dalam setiap strata ini ditandai dengan pangkat dan derajat. Tanggapan ini diperkuat oleh penelitian Jimmy (2012), bahwa stratifikasi berperan untuk menyusun, mengatur, dan mengawasi hubungan manusia dalam suatu masyarakat.

Berbeda juga yang di kemukakan oleh pak Sulfi bahwa peran stratifikasi sosial terhadap peternak di Desa Lompo Tengah berdampak positif, disebabkan meratanya informasi yang didapat dari luar tanpa memandang status mereka serta berbagai bantuan telah di dapatkan sehingga dapat membantu masyarakat dalam pemeliharaan ternak, begitu pula yang dikatakan oleh ibu Hasna menyatakan hal yang sama bahwa komunikasi, informasi dan bantuan pemerintah di Desa Lompo Tengah terbilang merata. Tanggapan ini perkuat oleh penelitian Sastramiharja (2010), bahwa stratifikasi sosial dalam masyarakat perdesaan yaitu melakukan kontribusi dan pemberian informasi dalam suatu masyarakat sebagai alat pemersatu sedangkan menurut pendapat pak Yendre, salah satu anggota kelompok tani/ternak di Desa Lompoh Tengah bahwa kelompoknnya kurang menjalin kerjasama, hanya di waktu tertentu saja seperti acara adat dsb. Namun dalam hal peternakan dan pertanian sangat kental bekerja secara induvidu meski mereka dalam sebuah kelompok seperti halnya dalam pemberian sapi potong betina produktif dan bantuan vaksin oleh pemerintah yang jarang didapatkan, hanya yang mendapatkan keluarga dari pemimpin adat atau yang sangat akrab dengan pemimpin adat. Pendapat ini tidak sesuai dengan penelitian Sastramiharja (2010), bahwa proses stratifikasi sosial merupakan proses 
sosial dan tindakan-tindakan sistem yang akan menyesuaikan diri atau menanggulangi suatu situasi yang dihadapinya, sistem sosial tersebut mempunyai elemen-elemen yaitu tujuan, kepercayaan, perasaan, norma, status peranan, kekuasan, derajat atau lapisan sosial, fasilitas dan wilayah.

\section{KESIMPULAN}

Stratifikasi sosial di Desa Lompo Tengah memiliki peranan yang berkaitan dengan harga diri yang merupakan hak yang dimiliki oleh setiap individu karena kedudukannya pada sebuah strata. Dalam setiap strata ini ditandai dengan pangkat, simbul-simbul yang menonjol seperti peringkat atau peranan khusus dan juga tingkah laku dalam keseharian khususnya pada peternak sapi potong.

Salah satu pendapat oleh peternak sapi potong di Desa Lompo Tengah tentang peran stratifikasi sosial masyarakat terhadap peternak dilihat dari distribusi hak-hak mereka masih kurang tepat sasaran sebagai contoh, pemberian pupuk bersubsidi untuk tanaman pakan hijauan pada kelompok tani dalam pemeliharaan ternaknya yang masih belum tersalurkan. Sedangkan menurut Pimpinan adat Desa Lompo Tengah berpendapat bahwa peran stratifikasi sosial yang ada di Desa Lompo Tengah memiliki peran yang cukup baik karena hubungan antara kepala desa dengan kelompok tani/ternak saling bekerja sama dalam mencpai tujuan kelompok tani/ternak yang disebabkan oleh tidak adanya keluhan dari peternak. Hal ini pun di kemukakan oleh salah satu peternak bahwa kondisi tentang peran stratifikasi sosial di Desa Lompo Tengah terbilang baik sebab hubungan antara pemimpin dan warga masyarakat khususnya peternak tetap dalam kondisi saling menghargai satu sama lain bahkan dari segi hak-hak yang telah dipenuhi terdistribusi secara merata tanpa melihat derajat dan statusnya. Disarankan, dari beberapa peternak yang ada di Desa Lompo Tengah umumnya memiliki latar belakang pendidikan serta pengalaman beternak yang berbeda-beda sehingga perlu dilakukan pendekatan sosialisasi yang lebih persuasif terkait permasalahan yang di alami dalam pemenuhan hak - hak serta kewajiban.

\section{DAFTAR PUSTAKA}

Abu, A. 2013. Ilmu Sosial Budaya Dasar. Jakarta: PT Rineka Cipta.

Hamdi, M. 2010. Kebijakan Pengembangan Peternakan Sapi Potong di Indonesia, Jurnal Litbang Pertanian. Fakultas Pertanian Mulawarman, Samarinda.

Jimmy. 2012. Masyarakat Sosial Stratifikasi Sosial. Bandung: Yudistira.

Munandar, Solaeman. 2011. Ilmu Sosial Dasar. Bandung: Tarsito. 
Sastramiharja. 2010. Setangkai Bunga Sosiologi. Jakarta: Lembaga Penerbit Fakultas Ekonomi Universitas Terbuka.

Soerjono, Soekanto. 2012. Sosiologi Suatu Pengantar. Jakarta: Rajawali Press.

Wahyuningsih. 2011. Masyarakat Desa. Bandung: Yudistira.

Ralf, D. 2013. Sistem Sosial. Jakarta: PT Raju Grafindo Persada. 